\title{
$\gamma$-Secretase Composed of PS1/Pen2/Aph1a Can Cleave Notch and Amyloid Precursor Protein in the Absence of Nicastrin
}

\author{
Guojun Zhao, ${ }^{1}$ Zhenyi Liu, ${ }^{1}$ Ma. Xenia G. Ilagan, ${ }^{1}$ and Raphael Kopan ${ }^{1,2}$ \\ ${ }^{1}$ Department of Developmental Biology, and ${ }^{2}$ Division of Dermatology, Washington University School of Medicine, St. Louis, Missouri 63110
}

\begin{abstract}
$\gamma$-Secretase is a multiprotein, intramembrane-cleaving protease with a growing list of protein substrates, including the Notch receptors and the amyloid precursor protein. The four components of $\gamma$-secretase complex-presenilin (PS), nicastrin (NCT), Pen2, and Aph1are all thought to be essential for activity. The catalytic domain resides within PS proteins, NCT has been suggested to be critical for substrate recognition, and the contributions of Pen2 and Aph1 remain unclear. The role of NCT has been challenged recently by the observation that a critical residue (E332) in NCT, which had been thought to be essential for $\gamma$-secretase activity, is instead involved in complex maturation. Here, we report that NCT is dispensable for $\gamma$-secretase activity. NCT-independent $\gamma$-secretase activity can be detected in two independent NCT-deficient mouse embryonic fibroblast lines and blocked by the $\gamma$-secretase inhibitors $N$ - $[N-(3,5-$ difluorophenacetyl-L-alanyl)]-S-phenylglycine $t$-butyl ester and L-685,458. This catalytic activity requires prior ectodomain shedding of the substrate and can cleave ligand-activated endogenous Notch receptors, indicating presence of this activity at the plasma membrane. Small interfering RNA knockdown experiments demonstrated that NCT-independent $\gamma$-secretase activity requires the presence of PS1, Pen2, and Aphla but can tolerate knockdown of PS2 or Aph1b. We conclude that a PS1/Pen2/Aph1a trimeric complex is an active enzyme, displaying biochemical properties similar to those of $\gamma$-secretase and roughly $50 \%$ of its activity when normalized to PS1 N-terminal fragment levels. This PS1/Pen2/Aphla complex, however, is highly unstable. Thus, NCT acts to stabilize $\gamma$-secretase but is not required for substrate recognition.
\end{abstract}

\section{Introduction}

$\gamma$-Secretase is a multiprotein, intramembrane-cleaving protease that cleaves its substrates within their transmembrane domains (TMDs) (Selkoe and Kopan, 2003). Biologically and clinically important $\gamma$-secretase substrates (Fagan et al., 2007; Selkoe and Wolfe, 2007; Dejaegere et al., 2008) include amyloid precursor protein (APP) (Haass, 2004; Thinakaran and Koo, 2008; Wolfe, 2008), ErbB4 (Ni et al., 2001), neuregulin (Bao et al., 2003), and the Notch receptors (De Strooper et al., 1999). The physiological and pathological roles of $\gamma$-secretase, its potential as a drug target in cancer and Alzheimer's disease (Miele et al., 2006; Roy et al., 2007; Aster et al., 2008; Tomita, 2009), and its novel function as an intramembrane-cleaving protease have generated intense commercial and academic interest in this mysterious enzyme. A better understanding of its structure, substrate recognition, and regulation will improve therapeutic exploitation of this complex protease (Kukar et al., 2008; Wolfe, 2009).

Genetic and biochemical studies have provided strong evidence that $\gamma$-secretase is a multiprotein complex comprised of

\footnotetext{
Received Aug. 5, 2009; revised Dec. 8, 2009; accepted Dec. 11, 2009.

This study was supported by National Institutes of Health (NIH) Grant AG025973 (R.K.), Alzheimer's Association Grant IIRG-03-5283 (R.K.), and NIH/National Institute on Aging Grant P50-AG05681 (Washington University Alzheimer's Disease Research Center). We are grateful to Dr. Philip C. Wong for providing NCT ${ }^{-1-}$ cells, Dr. Richard Rozmahel for the $\mathrm{NCT}^{+/-}$mice, Dr. Bart De Strooper for the PS ${ }^{\text {DKo }}$ cells and PS2 antibody, and Dr. Taisuke Tomita for PS2 antibody. We thank Dr. David Holtzman for critical reading of this manuscript and all members of the Kopan laboratory for helpful discussions and technical assistance.

Correspondence should be addressed to either Raphael Kopan or Guojun Zhao, McDonnell Science Building, Room 361, Box 8103, 660 South Euclid Avenue, St. Louis, M0 63110. E-mail: kopan@wustl.edu or guojunzhao@ wustl.edu.

DOI:10.1523/JNEUROSCI.3826-09.2010

Copyright $\odot 2010$ the authors $\quad 0270-6474 / 10 / 301648-09 \$ 15.00 / 0$
}

presenilin (PS; either PS1 or PS2), which contains the catalytic site (De Strooper et al., 1998; Wolfe et al., 1999; Li et al., 2000); nicastrin (NCT), which is thought to contain a substrate binding site (Shah et al., 2005); and Pen2 and Aph1 (1a, 1b, or 1c in rodents), which are of unclear contribution (De Strooper, 2003; Iwatsubo, 2004). Loss of any of these four proteins seemed to abolish $\gamma$-secretase activity (Francis et al., 2002; Takasugi et al., 2003), and only coexpression of the four components together reconstitutes $\gamma$-secretase activity in yeast (Edbauer et al., 2003) or SF9 cells (Hayashi et al., 2004), both of which lack endogenous $\gamma$-secretase activity. Consistent with the existence of several distinct $\gamma$-secretases, the active enzyme contains four components, each with potentially unique properties (Serneels et al., 2009).

PS is the founding member of a novel GxGD-type aspartyl protease family that includes the prokaryotic type IV prepilin peptidase (TFPP) and the eukaryotic signal peptide peptidase (SPP) and SPP-like proteases (SPPLs) (Haass and Steiner, 2002). In contrast to PS, TFPP, SPP, and SPPL proteins are single-chain enzymes, performing their activity without additional partners (Golde et al., 2009; Wolfe, 2009). It is still unclear why PS needs several cofactors. The precise role for NCT within $\gamma$-secretase has been controversial. NCT may facilitate substrate recognition (Shah et al., 2005; Dries et al., 2009) or may instead act to stabilize the $\gamma$-secretase complex (Shirotani et al., 2004; Zhang et al., 2005); a critical residue thought to be involved in substrate recognition (E332) was shown to be essential for $\gamma$-secretase maturation but not for its activity in mouse cells (Chavez-Gutierrez et al., 2008). Thus, the exact role of NCT remains controversial.

To elucidate the contribution of NCT to $\gamma$-secretase, we analyzed $\gamma$-secretase activity in two independent NCT knock-out cell 
A

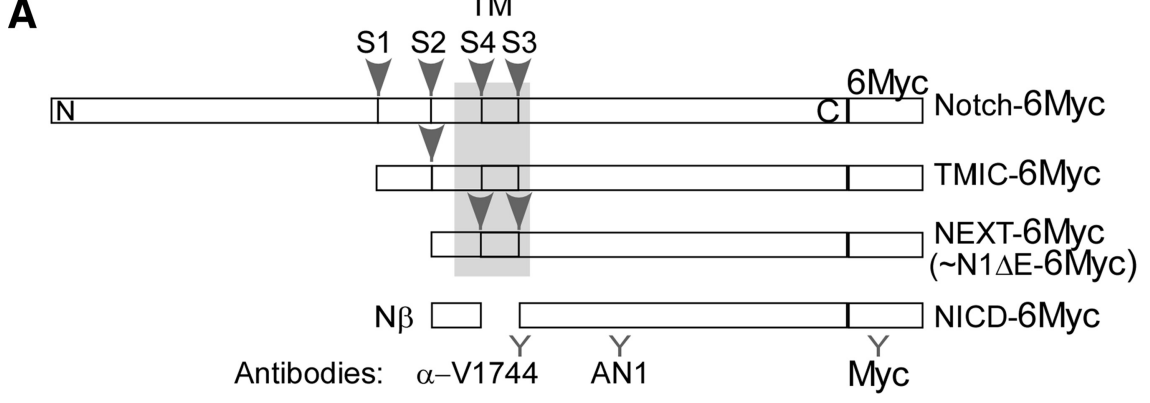

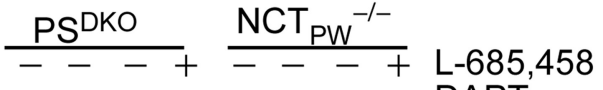

$--1+$

$-\overline{-}+\overline{+}$

DAPT

$--\overline{+}+$

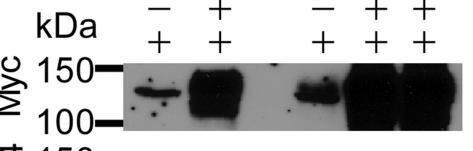

$-$
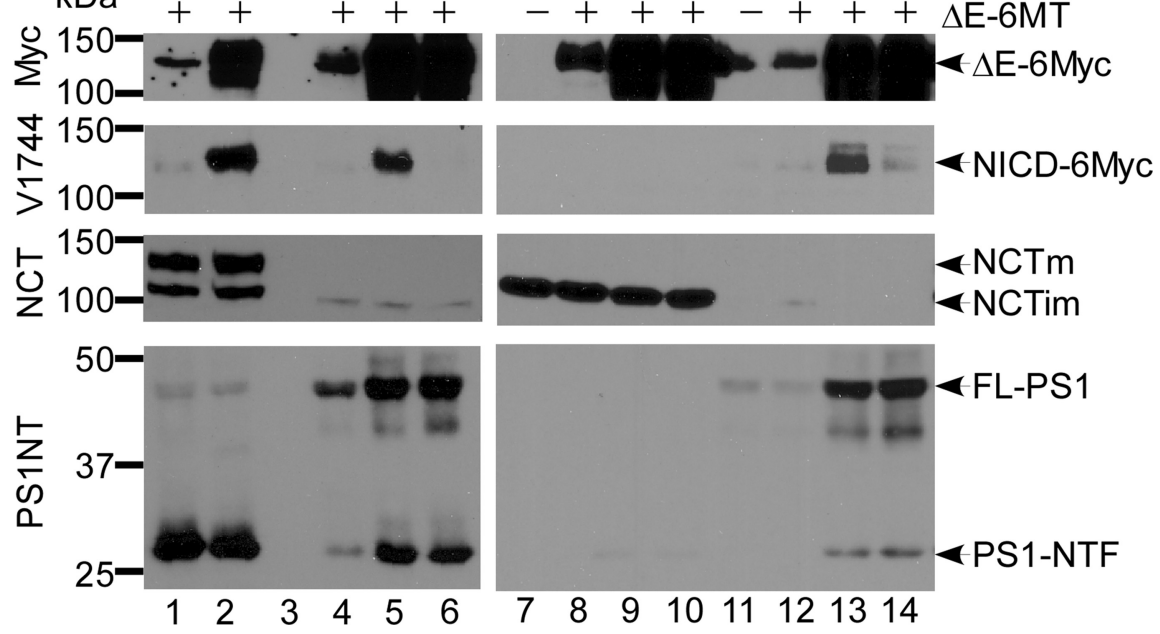

Figure 1. NICD is generated by a GSI-sensitive activity in $\mathrm{NCT}^{-1-}$ cells but not in $\mathrm{PS}^{\mathrm{DKO}}$ cells. Representative Western blots of NICD levels in pCS2 + $/ \mathrm{N} 1 \Delta \mathrm{E}-6 \mathrm{MT}$-transfected $\mathrm{NCT}_{\mathrm{PW}}{ }^{+/+}, \mathrm{NCT}_{\mathrm{PW}}{ }^{-/-}$, and PS ${ }^{\mathrm{DK} 0}$ cells are shown. $\boldsymbol{A}$, Schematic representation of Notch C-terminal fragments (CTFs). TMIC (transmembrane/intracellular), NEXT, and NICD denote Notch CTFs generated after S1, $\mathrm{S} 2$, and $\mathrm{S} 3$ site cleavages, respectively. $\boldsymbol{B}$, Cells were transiently transfected with $\mathrm{pCS} 2+/ \mathrm{N} 1 \Delta \mathrm{E}-6 \mathrm{MT}$ or $\mathrm{pCS} 2+$ empty vector. $\mathrm{N} 1 \Delta \mathrm{E}-6 \mathrm{MT}$ does not contain the extracellular domain, thereby making it a ligand-independent, direct substrate of $\gamma$-secretase. NICD accumulated in both $\mathrm{NCT}_{\mathrm{PW}}{ }^{+/+}$and $\mathrm{NCT}_{\mathrm{PW}}{ }^{-1-}$ cells cultured in the presence of proteasome inhibitors (lactacystin/MG262) but not in PS ${ }^{\text {DKO }}$ cells; DAPT and L-685,458 blocked NICD generation. NCTm and NCTim denote mature and immature forms of NCT, respectively. FL-PS1, Full-length PS1.

lines. We found that a complex containing PS1, Pen2, and Aph1a could cleave Notch and APP at the same sites used by holo- $\gamma$ secretase. The presence of catalytic activity demonstrated unequivocally that NCT is not required for $\gamma$-secretase substrate recognition, instead acting mainly to stabilize $\gamma$-secretase.

\section{Materials and Methods}

Plasmids. pCS2+/N1 $1 \mathrm{E}-6 \mathrm{MT}$, pCS2+/C99-6MT, and pcDNA3/PS1wt vectors have been described previously (Kopan et al., 1996; Schroeter et al., 2003).

Cell lines. NCT-deficient Ncstn ${ }^{t m 1 P c w} / N c s t n^{t m 1 P c w}\left(\mathrm{NCT}_{\mathrm{PW}}{ }^{-1-}\right)$ and wild-type $\left(\mathrm{NCT}_{\mathrm{PW}}{ }^{++}\right)$mouse embryonic fibroblast (MEF) lines were generous gifts from Dr. Philip C. Wong (Johns Hopkins University, Baltimore, MD) (Li et al., 2003). PS1/PS2 double knock-out (PS ${ }^{\text {DKO }}$ ) and PS1/PS2 wild-type $\left(\mathrm{PS}^{+/+}\right)$MEF lines were generous gifts from Dr. Bart De Strooper (Katholieke Universiteit Leuven, Leuven, and Flanders Institute for Biotechnology, Leuven, Belgium) (Herreman et al., 1999). We established $\mathrm{Ncstn}^{\text {tm1Rroz }} / \mathrm{Ncstn}^{\text {tm1 Rroz }} \mathrm{MEF}$ using $\mathrm{NCT}^{+/-}$breeders generously provided by Dr. Richard Rozmahel (University of Toronto, Toronto, Canada) (Nguyen et al., 2006) using a previously described method (Li et al., 2003) but with a slight modification. Briefly, embryonic day (E) 9.5 embryos were minced and resuspended in DMEM containing $0.025 \%$ trypsin/EDTA and incubated at $37^{\circ} \mathrm{C}$ for $20 \mathrm{~min}$. DMEM sup-
Lac/ MG262

plemented with $10 \%$ fetal bovine serum (FBS) was added to neutralize the trypsin/EDTA, and the cells were further dissociated by pipetting, plated into 24-well plates, and subsequently immortalized with polyoma large $\mathrm{T}$ antigen. Immortalized NCT knock-out clones were confirmed by both genotyping and Western blot analysis.

Cell culture and plasmid transfection. For most experiments, cells were maintained in DMEM supplemented with $10 \%$ FBS, $2 \mathrm{~mm}$ glutamine and incubated at $37^{\circ} \mathrm{C}$ and $5 \% \mathrm{CO}_{2}$. To examine the generation of Notch intracellular domain (NICD) and amyloid intracellular domain (AICD), cells were transfected with $\mathrm{pCS} 2+/ \mathrm{N} 1 \Delta \mathrm{E}-6 \mathrm{MT}$ and $\mathrm{pCS} 2+/ \mathrm{C} 99-6 \mathrm{MT}$ vectors or empty vector using Lipofectamine 2000 (Invitrogen) or FuGENE HD (Roche) transfection reagents, according to the manufacturers' instructions. The transfected cells were subsequently cultured in the presence or absence of proteasome inhibitors (4.5 $\mu \mathrm{M}$ lactacystin/0.15 $\mu \mathrm{M}$ MG262; Calbiochem) and $\gamma$-secretase inhibitors [either $1 \mu \mathrm{M} \mathrm{N}$-[N-(3,5difluorophenacetyl-L-alanyl)]-S-phenylglycine $t$-butyl ester (DAPT) or $1 \mu \mathrm{M} \mathrm{L}-685,458$; Calbiochem].

$A \beta$ analysis. pCS2+/C99-6MT-transfected cells were cultured in OPTI-MEM supplemented with 7\% FBS, 2 mM glutamine, $10 \mathrm{~mm}$ nonessential amino acids, $10 \mu \mathrm{M}$ phosphoramidon disodium (Sigma), with or without proteasome inhibitors and $\gamma$-secretase inhibitors. Both cells and conditioned media (CMs) were collected 20-22 h later. The CMs were supplemented with $1 \mathrm{~mm}$ AEBSF [4-(2-aminoethyl) benzenesulfonyl fluoride hydrochloride; Roche], centrifuged, and analyzed by A $\beta$ ELISA (Invitrogen) according to the manufacturer's instructions, but with a slight modification. The incubation time for antibodies and stabilized chromogen and the time for each wash step were increased to make testing lower levels of $\mathrm{A} \beta$ more accurate. Each sample was run in duplicate. The CMs from cells transfected with empty vector were used as blanks.

Coculture of $\mathrm{NCT}_{R R}{ }^{-1-}$ cells with ligand-expressing cells. $\mathrm{NCT}_{\mathrm{RR}}{ }^{-1-}$ or PS ${ }^{\mathrm{DKO}}$ cells were coseeded with either CHO-DLL1-IRES-GFP (CHO: Chinese hamster ovary; IRES: internal ribosome entry site; GFP: green fluorescent protein) or CHO-GFP control cells (these two cell lines have been described previously) (Ong et al., 2008), cultured for $24 \mathrm{~h}$, and then treated with or without lactacystin/MG262 and DAPT. The cells were collected after $20 \mathrm{~h}$ and lysed with lysis buffer A containing $8 \mathrm{~m}$ urea, $1 \%$ SDS, 50 mм Tris- $\mathrm{HCl}$, pH 6.8, 2 mм EDTA, 2 mм DTT, and $1 \times$ protease inhibitor cocktail (Roche) (Zhao et al., 2004).

siRNA transfection. ON-TARGETplus small interfering RNA (siRNA) smart pools targeting mouse PS1, PS2, Pen2, Aph1a, and Aph1b were purchased from Dharmacon (see supplemental Table 1, available at www.jneurosci.org as supplemental material for sequences). ONTARGETplus nontargeting siRNA control (Dharmacon) was used as a negative control. siRNAs were transfected into $\mathrm{NCT}^{-1-}$ cells using DharmaFect 1 (Dharmacon) according to the manufacturer's instructions. The cells were cultured in complete medium for $48 \mathrm{~h}$ and then transfected with pCS2+/N1 $\Delta \mathrm{E}-6 \mathrm{MT}$ vector. Knockdown efficiency was determined by either Western blotting or quantitative reverse transcription (qRT)-PCR.

$q R T-P C R$. siRNA-transfected $\mathrm{NCT}_{\mathrm{RR}}{ }^{-1-}$ cells were cultured for $68 \mathrm{~h}$. The total RNA was then isolated using RNeasy Micro kit (Qiagen) according to the manufacturer's instructions. The reverse transcription was 
performed using SuperScript II reverse transcriptase (Invitrogen) with oligo $(\mathrm{dT})_{16}$ as the primer. Quantitative PCR was performed according to previously described methods (Lee et al., 2007) (see supplemental Table 2, available at www.jneurosci.org as supplemental material for primer sequences).

EDTA treatment. $\mathrm{NCT}_{\mathrm{RR}}{ }^{-1-}, \mathrm{NCT}_{\mathrm{PW}}{ }^{-1-}$, $\mathrm{PS}^{\mathrm{DKO}}$, and $\mathrm{PS}^{+/+}$cells were washed once with HBSS buffer (without $\mathrm{Ca}$ or $\mathrm{Mg}$ ) and incubated in $1.5 \mathrm{~mm}$ EDTA/HBSS buffer for $40 \mathrm{~min}$ at $37^{\circ} \mathrm{C}$. For $\gamma$-secretase inhibition, cells were treated with $1 \mu \mathrm{M}$ DAPT for $4 \mathrm{~h}$ before and during EDTA incubation.

Western blotting and antibodies. Cells were lysed in lysis buffer A with brief sonication, and the protein concentration was determined using a BCA kit (Pierce). Twenty to $30 \mu \mathrm{g}$ of total protein per sample was analyzed by SDSPAGE/Western blot analysis. The following antibodies were used in this study: anti-V1744 (Cell Signaling Technology), anti-NCT (N1660, Sigma), anti-PS1-NTF (Santa Cruz Biotechnology), anti-PS2-CTF antibodies B24.2 and G2L [generous gifts from Dr. Bart De Strooper (Herreman et al., 1999) and Dr. Taisuke Tomita (Tomita et al., 1998), respectively], antiAphla (Covance), anti-Notch1 ANK domain (mAN1) (Huppert et al., 2000), anti- $\beta$-actin (Sigma), and anti-myc (9E10).

\section{Results}

NICD is generated in $\mathrm{NCT}^{-/-}$cells but not in $\mathrm{PS}^{\text {DKO }}$ cells

All GxGD proteases prefer substrates that have undergone ectodomain shedding, and all, including PS, contain a substrate recognition domain (Kornilova et al., 2005). We hypothesized that if the role of NCT was to stabilize $\gamma$-secretase, but not to bind substrates, we should be able to detect $\gamma$-secretase activity in the absence of NCT. To test this hypothesis, we transiently transfected wild-type $\left(\mathrm{NCT}_{\mathrm{PW}}{ }^{+/}\right)$and $\mathrm{NCT}_{\mathrm{PW}}{ }^{-/-}$cells (from Dr. P.C. Wong) with ectodomain-truncated, Notch1-expressing vector $(\mathrm{pCS} 2+/ \mathrm{N} 1 \Delta \mathrm{E}-6 \mathrm{MT})$. The truncated Notch $1 \Delta \mathrm{E}-6$ myc protein is a ligand-independent and direct substrate of $\gamma$-secretase, similar to Notch extracellular truncation (NEXT) (Fig. 1A). To enhance detection, transfected cells were cultured in the presence of proteasome inhibitors that reduce the turnover of the NICD (Tagami et al., 2008) and increase the sensitivity of detection for this cleavage product. Western blot analyses with an anti-myc antibody indicated that N1 $\Delta \mathrm{E}-6 \mathrm{MT}$ expression levels in $\mathrm{NCT}_{\mathrm{PW}}{ }^{+/+}$and $\mathrm{NCT}_{\mathrm{PW}}{ }^{-1-}$ cells were equivalent and that proteasome inhibition increased the amounts of N1 $\Delta \mathrm{E}-6 \mathrm{MT}$ (Fig. $1 B$, lanes 2,5 , and 6 ), presumably by decreasing degradation of uncleaved molecules. Consistent with previous reports (Zhang et al., 2005), we also observed PS1 N-terminal fragment (PS1-NTF) in $\mathrm{NCT}_{\mathrm{PW}}{ }^{-1-}$ cells, an indication that some presenilinase activity remained (Fig. $1 B$, lane 4 ). We then assessed N1 $\Delta$ E-6MT cleavage between G1743-V1744 with an epitope-specific antibody ( $\alpha$ VLLS; i.e., V1744 antibody). When probed with anti-V1744 antibody, NICD was detected in $\mathrm{NCT}_{\mathrm{PW}}{ }^{+/+}$cells as expected. Significantly, in the presence of proteasome inhibitors, PS1-NTF and NICD accumulated in $\mathrm{NCT}_{\mathrm{PW}^{-/-}}$cells (Fig. $1 B$, lane 5). To examine whether the NICD generated in $\mathrm{NCT}_{\mathrm{PW}}{ }^{-1-}$ cells was produced by an aspartyl protease, we asked whether this NCTindependent protease was sensitive to a selective $\gamma$-secretase inhibitor (GSI), DAPT (N-[N-(3,5-difluorophenacetyl-Lalanyl)]-S-phenylglycine $t$-butyl ester) (Weihofen et al., 2003).
DAPT completely abolished the generation of NICD in $\mathrm{NCT}_{\mathrm{PW}}{ }^{-1-}$ cells (Fig. $1 B$, lane 6), suggesting that NICD is generated by a $\gamma$-secretase-like activity in the absence of NCT. Generation of NICD in $\mathrm{NCT}_{\mathrm{PW}}{ }^{-1-}$ cells was also blocked by a structurally distinct GSI, L-685,458 (Fig. 1 B, lane 14). We therefore concluded that in the $\mathrm{NCT}_{\mathrm{PW}}{ }^{-1-}$ cell line, Notch is cleaved at the peptide bond between G1743 and V1744 [site 3 (S3)] by a GSI-sensitive activity.

To our knowledge, $\gamma$-secretase is the only enzyme that cleaves Notch1 at its S3 site, but the existence of other enzymes with $\gamma$-secretase-like activity has been proposed to compensate for PS loss (Huppert et al., 2005). To ask whether a Notch intramembrane protease exists in other $\gamma$-secretase-deficient cells, we examined NICD generation in PS ${ }^{\text {DKO }}$ cells, which are deficient in both PS1 and PS2. Western blot analyses showed that both PS ${ }^{\text {DKO }}$ and $\mathrm{NCT}_{\mathrm{PW}}{ }^{-1-}$ cells expressed high levels of N1 $\mathrm{E}-6 \mathrm{MT}$, yet NICD was undetectable in samples from PS ${ }^{\text {DKO }}$ cells under the same conditions that allow NICD accumulation in $\mathrm{NCT}_{\mathrm{PW}}{ }^{-1-}$ samples (Fig. $1 B$, lanes 9 and 13). The generation of NICD in PS ${ }^{\mathrm{DKO}}$ cells can be rescued by transfection of wild-type PS1 or PS2 but not an inactive aspartyl mutant PS1, confirming that the failure to generate NICD by PS ${ }^{\text {DKO }}$ cells is not an indication of other defects (supplemental Fig. 2, available at www.jneurosci. org as supplemental material) (Schroeter et al., 2003). Overall, these results indicate that a $\gamma$-secretase-like activity in $\mathrm{NCT}_{\mathrm{PW}}{ }^{-1-}$ cells cleaves Notch to generate NICD and that this activity does not exist in $\mathrm{PS}^{\mathrm{DKO}}$ cells.

\section{Generation of NICD is observed in two independent $\mathrm{NCT}^{-1-}$ lines}

We noticed a faint cross-reacting band with mobility similar to that of immature $\mathrm{NCT}$ in $\mathrm{NCT}_{\mathrm{PW}}{ }^{-1-}$ cells (Fig. $1 B$ ). $\mathrm{NCT}_{\mathrm{PW}}{ }^{-1-}$ cells were derived from an NCT knock-out embryo in which the critical part of the DAP (DYIGS and peptidase homologous region) domain (exon 9, intron 9, and part of exon 10) was replaced 


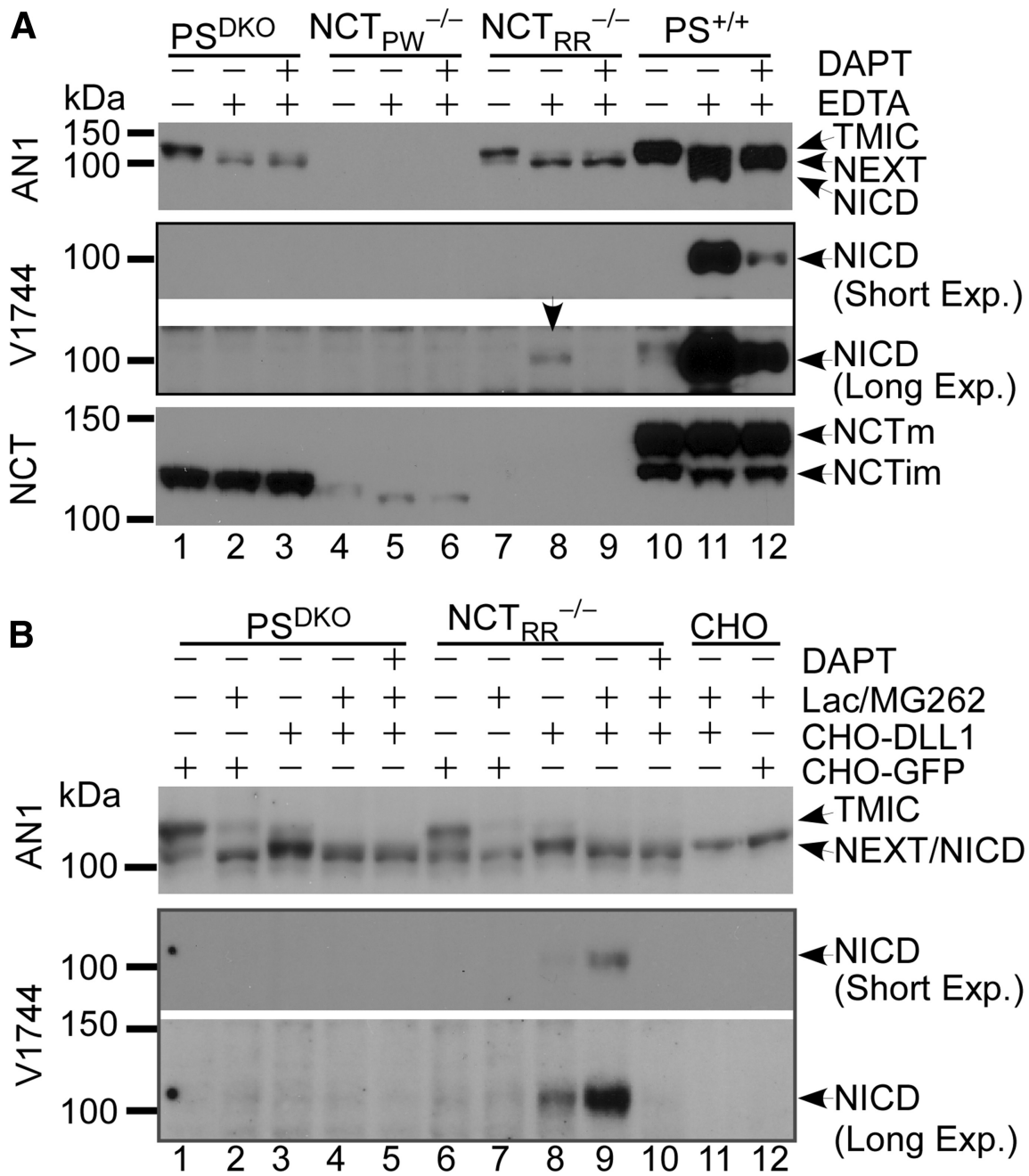

Figure 3. NICD is generated from endogenous Notch 1 in $\mathrm{NCT}^{-1-}$ cells but not in PS ${ }^{\mathrm{DKO}}$ cells. $A$, Representative Western blots of NICD levels in EDTA-treated cells. Metalloprotease-mediated shedding occurs after calcium chelation-induced dissociation of endogenous Notch1. EDTA treatment led to reduced amounts of furin-cleaved Notch [transmembrane/intracellular (TMIC)] and increased amounts of NEXT, indicating that upon EDTA treatment Notch1 undergoes $\$ 2$ site cleavage in $\mathrm{PS}^{\mathrm{DKO}}, \mathrm{NCT}_{\mathrm{RR}}{ }^{-/-}$, and $\mathrm{PS}^{+/+}$cells. Although endogenous Notch1 levels are similar in both $\mathrm{PS}^{\mathrm{DKO}}$ and NCT ${ }_{\mathrm{RR}}{ }^{-/-}$cells, NICD is produced from NEXT only in $\mathrm{NCT}_{\mathrm{RR}}{ }^{-1-}$ (arrow) cells but not in PS ${ }^{\mathrm{DK} 0}$ cells. $\mathrm{NCT}_{\mathrm{PW}}{ }^{-1-}$ cells do not express endogenous Notch1. B, Representative Western blots of NICD levels in $\mathrm{NCT}_{\mathrm{RR}}{ }^{-1-}$ cells cocultured with Notch ligand-expressing cells. NICD is generated in $\mathrm{NCT}_{\mathrm{RR}}{ }^{-1-}$ cells from endogenous Notch1 receptors after activation by ligands presented by neighboring cells. Note that NICD was only detected in coculture of $\mathrm{NCT}_{\mathrm{RR}}{ }^{-1-}$ cells with CHO-DLL1 cells but not in the other cocultures or $\mathrm{CHO}$ cells alone. DAPT treatment blocked the generation of NICD. Long Exp., Long exposure; Short Exp., short exposure.

with the neomycin resistance gene ( $\mathrm{Li}$ et al., 2003). To test whether $\gamma$-secretase-like activity in this specific cell line was due to residual NCT expression, we analyzed a second, independently generated NCT knock-out mouse line (from Dr. Richard Rozmahel) in which exon 3 and a part of exon 4 had been deleted, and therefore splicing downstream of the deletion would shift the reading frame (Nguyen et al., 2006). We isolated $\mathrm{NCT}_{\mathrm{RR}}{ }^{-1-} \mathrm{MEF}$ cells from $\mathrm{E} 9.5 \mathrm{NCT}_{\mathrm{RR}}{ }^{-1-}$ embryos and examined NCT production and $\gamma$-secretase activity in these cells. No NCT immunoreactivity was observed in $\mathrm{NCT}_{\mathrm{RR}}{ }^{-l-}$ cell extracts (Fig. 2, lanes 9-12). Importantly, as in $\mathrm{NCT}_{\mathrm{PW}}{ }^{-1-}$ cells, endoproteolysis of $\mathrm{PS} 1$ in $\mathrm{NCT}_{\mathrm{RR}}{ }^{-/-}$ was also observed, confirming that PS endoproteolysis does not require NCT. Accordingly, in the presence of proteasome inhibitors we observed NICD accumulation in $\mathrm{NCT}_{\mathrm{RR}}{ }^{-/-}$cells (Fig. 2, lane $11)$. In this cell line, NICD production was again blocked by either L-685,458 (Fig. 2, lane 12) or DAPT (Fig. 3A). Overall, these data clearly demonstrate that generation of NICD by residual $\gamma$-secretase-like activity is independent of the specific $\mathrm{NCT}^{-/-}$line used.

\section{Endogenous Notch can be cleaved by the $\gamma$-secretase-like activity in NCT ${ }^{-1-}$ cells but not in PS ${ }^{\mathrm{DKO}}$ cells}

The $\gamma$-secretase-like activity that survived removal of NCT may only cleave ectopically expressed Notch substrates lacking an extracellular domain. To ask whether this enzyme could cleave endogenous Notch, we examined the cleavage of endogenous Notch1 receptors under conditions that induce ectodomain shedding at the cell surface. In the absence of ligands, a calcium-stabilized negative regulatory region prevents metalloprotease access to the S2 cleavage site (Gordon et al., 2007). Ligand binding or treatment with EDTA (Rand et al., 2000) is thought to result in a conformational change that leads to the exposure of the S2 cleavage site and subsequent cleavage by ADAM (a disintegrin and metalloproteinase) metalloproteases (Kopan and Ilagan, 2009), generating NEXT (Fig. 1A), a direct substrate of $\gamma$-secretase. Western blot analyses showed that all the MEF lines (except for $\mathrm{NCT}_{\mathrm{PW}}{ }^{-1-}$ ) expressed endogenous Notch1. To test whether the generation of NICD from endogenous Notch 1 can occur without NCT protein, PS ${ }^{\mathrm{DKO}}$ cells and $\mathrm{NCT}_{\mathrm{PW}}{ }^{-1-}, \mathrm{NCT}_{\mathrm{RR}}{ }^{-1-}$, and wild-type MEFs were treated with or without EDTA to induce $\mathrm{S} 2$ cleavage (see shift in mobility in Fig. 3A). Importantly, after treatment with EDTA, DAPT-sensitive NICD generation was detected in $\mathrm{NCT}_{\mathrm{RR}}{ }^{-1-}$ and wild-type cells (Fig. 3A, lanes 8-9 and 1112). Moreover, after EDTA treatment, endogenous NICD was observed in $\mathrm{NCT}^{-1-}$ cells even without proteasome inhibition (Fig. $3 A, B$ ). This result confirms that ectodomain shedding is required for the release of NICD in $\mathrm{NCT}_{\mathrm{RR}}{ }^{-1-}$ cells (Fig. 3A, compare lanes 7 and 8). In contrast, Notch1-expressing PS ${ }^{\mathrm{DKO}}$ cells accumulated the S2 cleavage product NEXT but did not produce NICD (Fig. $3 A$, lanes 1 and 2). Because removal of calcium with EDTA occurs at or near the cell surface and because both ADAM10 and Notch1 are mainly localized at the plasma membrane (van Tetering et al., 2009), this result suggests that the NCT-deficient $\gamma$-secretase-like protease performs its activity at or close to the plasma membrane.

To obtain physiologically relevant evidence that $\gamma$-secretaselike activity reached the cell surface, we asked whether the Notch1 receptors in $\mathrm{NCT}_{\mathrm{RR}}{ }^{-1-}$ cells could be activated by ligands presented on neighboring cells. We cocultured $\mathrm{NCT}_{\mathrm{RR}}{ }^{-l-}$ (or control PS ${ }^{\text {DKO }}$ cells) with either ligand-expressing (CHO-DLL1) or control (CHO-GFP) cells in the presence or absence of proteasome inhibitors. Western blot analysis shows that coculture with CHO-DLL1 cells induced endogenous Notch1 S2 cleavage (Fig. $3 B)$. As expected, if the enzyme reached the cell surface, endogenous NICD was detected in $\mathrm{NCT}_{\mathrm{RR}}{ }^{-1-}$ cells cocultured with 
CHO-DLL1 (Fig. 3B, lanes 8 and 9) but not in $\mathrm{NCT}_{\mathrm{RR}}{ }^{-1-}$ cells cocultured with CHO-GFP. DAPT blocked the generation of NICD in $\mathrm{NCT}_{\mathrm{RR}}{ }^{-1-}$ cells (Fig. 3B, lane10), and PS ${ }^{\mathrm{DKO}}$ cells cocultured with CHO-DLL1 cells did not release NICD, indicating that NICD was not generated by the CHO cells (Fig. $3 B$, lanes 4, 5, 11, and 12). Together, these results confirm that the $\gamma$-secretase-like activity in $\mathrm{NCT}^{-1-}$ cells requires substrate ectodomain shedding and can reach the plasma membrane to mediate the cleavage of ligand-activated Notch.

\section{C99 is converted into AICD and A $\beta$ in} $\mathrm{NCT}^{-1-}$ cells but not in PS ${ }^{\mathrm{DKO}}$ cells

Another important substrate of $\gamma$-secretase is APP, which is involved in the pathogenesis of Alzheimer's disease. Since mutations in NCT were shown previously to differentially affect APP and Notch processing (Chen et al., 2001), we asked whether a truncated APP substrate (C99) could be processed in $\mathrm{NCT}^{-1-}$ cells by the $\gamma$-secretaselike activity. We transiently transfected $\mathrm{PS}^{\mathrm{DKO}}$, $\mathrm{NCT}_{\mathrm{PW}}{ }^{-1-}, \mathrm{NCT}_{\mathrm{RR}}{ }^{-1-}$, and wild-type MEF cells with C99-6myc-expressing vector. Western blot analyses confirmed that a DAPT-

sensitive fragment (AICD-6myc) present in wild-type cells but not in $\mathrm{PS}^{\mathrm{DKO}}$ cells was also seen in two NCT-deficient cell lines (Fig. $4 A$, lanes 3, 7, and 13), suggesting that $\mathrm{NCT}^{-1-}$ cells are able to cleave $\mathrm{C} 99$ (Fig. $4 \mathrm{~A}$; note that proteasome inhibition was required to detect the cleavage products). A longer exposure detected low amounts of AICD-myc in $\mathrm{NCT}_{\mathrm{PW}}{ }^{-1-}$ cells not treated with proteasome inhibitors (supplemental Fig. 1, available at www.jneurosci.org as supplemental material). To address whether $\mathrm{A} \beta$ was also produced in $\mathrm{NCT}^{-1-}$ cells, we performed ELISA analysis on conditioned media to determine the secreted $\mathrm{A} \beta$ levels. $\mathrm{A} \beta 40$ was detected in conditioned media from $\mathrm{NCT}^{-1-}$ cells but not from $\mathrm{PS}^{\mathrm{DKO}}$ cells (Fig. $4 B$ ) and was abolished after DAPT addition (Fig. $4 B$ ). We were unable to detect $\mathrm{A} \beta 42$ levels with the $\mathrm{A} \beta 42$ ELISA kit, likely due to the low transfection efficiency of MEF cells. Collectively, these data indicate that not only can the residual $\gamma$-secretase activity cleave APP, it can proceed from the $\varepsilon$-cleavage site to the $\gamma$-cleavage site, a hallmark of $\gamma$-secretase (Tanzi and Bertram, 2005; Haass and Selkoe, 2007), even in the absence of NCT.

\section{$\gamma$-Secretase-like activity in $\mathrm{NCT}^{-/-}$cells is PS1 dependent}

The fact that two unrelated $\gamma$-secretase inhibitors abolished the $\gamma$-secretase-like activity in $\mathrm{NCT}^{-1-}$ cell lines, and that $\mathrm{PS}^{\mathrm{DKO}}$ cells did not exhibit this activity, strongly implies that PS is the active enzyme in $\mathrm{NCT}^{-1-}$ cells. To test this, we used siRNAs to knock down PS1 and PS2 (alone or together) in $\mathrm{NCT}_{\mathrm{RR}}{ }^{-1-}$ cells transfected with N1 $1 \mathrm{E}-6 \mathrm{MT}$. Western blot analysis confirmed that PS1 siRNA markedly decreased both full-length PS1 and PS1-NTF (Fig. 5A, lanes 3 and 4), whereas control siRNA and PS2 siRNA did not affect PS1 protein level (Fig. 5A, lanes 1, 2, 5, and 6). Interestingly, PS1 knockdown alone was sufficient to significantly diminish NICD production, whereas knockdown of PS2 did not show an obvious effect (Fig. 5A, lanes 5-6). Since we could not detect PS2 in these cells with two different established antibodies (Tomita et al., 1998; Herreman et al., 1999), the effi- ciency of PS2 siRNA knockdown was confirmed by qRT-PCR (Fig. 5B). Accordingly, cotransfection of PS1 siRNA together with PS2 siRNA did not further reduce NICD amounts (Fig. 5A, lanes 7 and 8). Similar results were obtained with $\mathrm{NCT}_{\mathrm{PW}}{ }^{-1-}$ cells (supplemental Fig. 3, available at www.jneurosci.org as supplemental material). These results suggest that PS1 or a PS1containing enzyme in $\mathrm{NCT}^{-1-}$ cells mediates NICD production.

To ask whether PS2 can contribute to $\gamma$-secretase activity in $\mathrm{NCT}^{-1-}$ cells, we overexpressed PS2 in $\mathrm{NCT}_{\mathrm{RR}}{ }^{-1-}$ cells. We first performed PS1 mRNA knockdown and then asked whether cotransfection of the substrate (pCS2+/N1 $1 \mathrm{E}-6 \mathrm{MT})$ with either human PS1 or PS2 expression vector into these mouse PS1depleted $\mathrm{NCT}^{-1-}$ cells would restore the $\gamma$-secretase activity. While both PS1 and PS2 restored $\gamma$-secretase activity equally well in PS ${ }^{\text {DKO }}$ cells, only human PS1, but not human PS2, restored $\gamma$-secretase activity in PS1 siRNA-transfected $\mathrm{NCT}^{-/-}$cells (supplemental Fig. 2, available at www.jneurosci.org as supplemental material). These data confirmed that PS2 protein could not contribute to the $\gamma$-secretase activity in $\mathrm{NCT}^{-1-}$ cells.

\section{Pen2 and Aph1a are involved in the $\boldsymbol{\gamma}$-secretase-like activity}

To ask whether PS1 acted as a single-molecule protease like SPP (Golde et al., 2009), we examined whether Pen2 and Aph1 were still required for the PS1 activity in the absence of NCT. We performed Pen2 or Aph1 knockdown in $\mathrm{NCT}_{\mathrm{RR}}{ }^{-1-}$ cells using siRNA pools and confirmed the efficiencies of siRNA knockdown by qRT-PCR (Fig. $6 B, D$ ). Western blot analyses demonstrated that knockdown of Pen2 did not decrease the amount of fulllength PS1 but dramatically reduced PS1-NTF levels and, concomitantly, the amounts of NICD (Fig. 6A, lanes 3-8). Of the three murine Aph1 genes (Ma et al., 2005; Serneels et al., 2005), only knockdown of Aph1a in $\mathrm{NCT}_{\mathrm{RR}}{ }^{-1-}$ cells reduced PS1-NTF and NICD levels, whereas full-length PS1 levels remained unchanged (Fig. 6C, lanes 3-6). Aph1b siRNA did not impact PS1- 
A
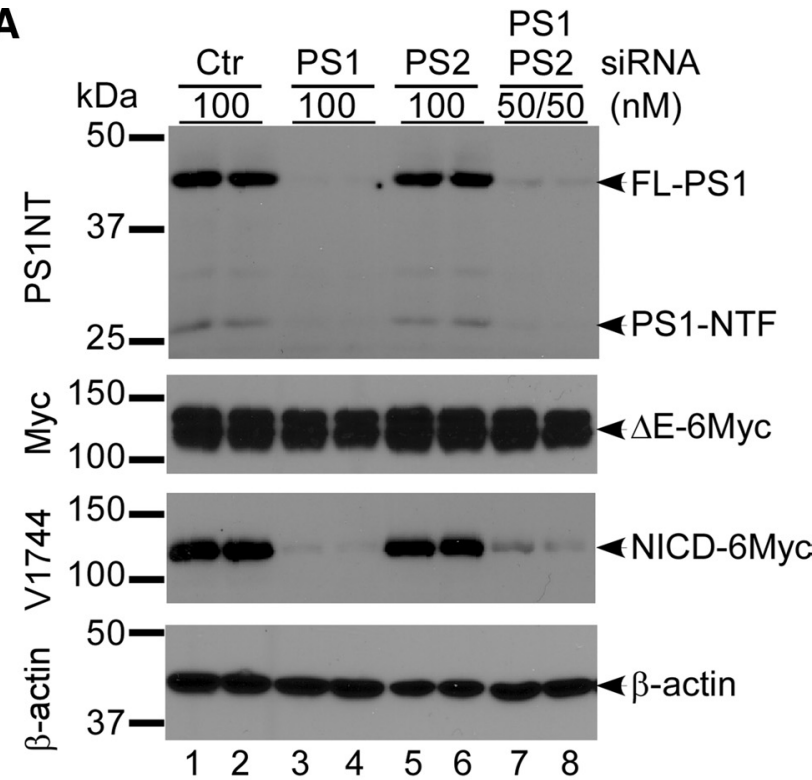

B

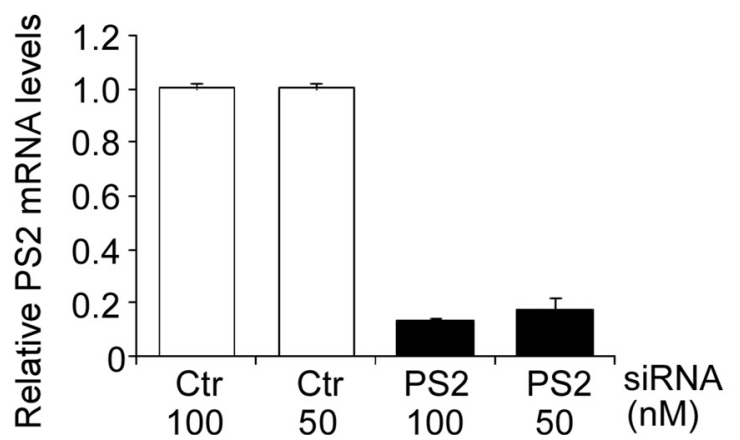

Figure 5. $\quad \gamma$-Secretase-like activity in $\mathrm{NCT}^{-1-}$ cells is PS1 dependent. $\boldsymbol{A}$, Representative Western blots of NICD levels in PS siRNA-transfected $\mathrm{NCT}_{\mathrm{RR}}{ }^{-1-}$ cells. $\mathrm{NCT}_{\mathrm{RR}}{ }^{-1-}$ cells were transfected with PS1, PS2, PS1-plus-PS2, or nontargeting control siRNAs. The cells were subsequently transfected with $\mathrm{pCS} 2+/ \mathrm{N} 1 \Delta \mathrm{E}-6 \mathrm{MT}$ and cultured in the presence of proteasome inhibitors. Cell lysates were then analyzed by Western blotting with antibodies against PS1NT, Myc, V1744, and $\beta$-actin. PS1 siRNA markedly decreased both full-length PS1 (FL-PS1) and PS1-NTF. Although the levels of N1 $\Delta \mathrm{E}-6$ myc are similar in every extract, NICD accumulation was strikingly reduced in PS1 siRNA-transfected cells and in PS1-plus-PS2 siRNA-transfected cells but not in siRNA control (Ctr)- or PS2 siRNA-transfected cells. $\boldsymbol{B}$, Since the PS2 proteins in these $\mathrm{NCT}^{-1-}$ cells were undetectable by Western blot analysis using two well-characterized antiPS2 antibodies (data not shown), knockdown of PS2 was confirmed by qRT-PCR.

NTF or NICD level (Fig. 6C, lanes 7-10). Similar results were obtained with $\mathrm{NCT}_{\mathrm{PW}}{ }^{-1-}$ cells (supplemental Fig. 3, available at www.jneurosci.org as supplemental material). These results suggest that in $\mathrm{NCT}^{-1-}$ cells, an unstable $\gamma$-secretase isomorph composed of three proteins (PS1, Pen2, and Aph1a) provides $\gamma$-secretase activity that correlates strongly with the amount of endoproteolytically processed PS1-NTF but not full-length PS1. Thus, PS1 activity requires endoproteolysis and the functions of Pen2 and Aph1a.

\section{Trimeric $\gamma$-secretase retains $50 \%$ of the enzyme activity}

To accurately evaluate the remaining $\gamma$-secretase activity in $\mathrm{NCT}^{-1-}$ cells, we tried to establish a cell-free assay. However, although we could readily detect $\gamma$-secretase activity in solubilized membranes from wild-type cells, we failed to detect any $\gamma$-secretase-like activity in solubilized membranes from $\mathrm{NCT}^{-/-}$ cells (data not shown). It is likely that the trimeric $\gamma$-secretase complex lacking NCT is highly unstable in the detergent solution, as it was unstable in blue native gels (data not shown). Therefore, we compared the relative activity of $\gamma$-secretase in $\mathrm{NCT}^{-/-}$cells and wild-type cells using a semiquantitative Western blot analysis of extracts isolated from cells cultured in the presence of proteasome inhibitors. As shown in supplemental Figure 4 (available at www.jneurosci.org as supplemental material), in cell lysates containing equivalent levels of PS1 NTF fragments, $\mathrm{NCT}^{-1-}$ cells produced $50-55 \%$ of the NICD produced by wild-type lines. From these data, we can conclude that the trimeric enzyme is much more active than would be expected if NCT was providing the substrate recognition function in the complex. We cannot rule out an indirect contribution by NCT to overall activity due to increased enzyme stability.

\section{Discussion}

PS, NCT, Pen2, and Aph1 are the four proteins essential for reconstituting robust $\gamma$-secretase activity (De Strooper, 2003; Iwatsubo, 2004; Spasic and Annaert, 2008). With the exception of PS, which harbors the catalytic site of $\gamma$-secretase, the precise contributions of the other proteins to $\gamma$-secretase activity remain unclear, and PS remains the only GxGD protease that requires partners for its protease activity. Here, we have provided direct evidence that when PS1/Pen2/Aph1a are present, $\gamma$-secretase can assemble and acquire catalytic activity without NCT, cleaving both Notch and APP (C99) substrates. Furthermore, this three-protein enzyme remains biochemically similar to the four-protein enzyme: both are DAPT and L-685,458 sensitive (Fig. $1 B$ ), both generate NICD at the $S 3$ site (Figs. 1-3), and both cleave APP at $\varepsilon$ and $\gamma$ to release AICD and A $\beta 40$, respectively (Fig. 4). Importantly, ligandmediated activation of endogenous Notch can also be observed in $\mathrm{NCT}^{-1-}$ cells (Fig. 3B). However, this residual activity is not sufficient to permit survival of $\mathrm{NCT}^{-/-}$embryos (Li et al., 2003; Nguyen et al., 2006).

As this manuscript was being prepared, another group identified NCT-independent PS1 mutants (PS1 S438P or PS1 F411Y/ S438P) (Futai et al., 2009), suggesting that perhaps this S438P mutation increased complex stability. We aligned PS proteins with their homologues and found that a Pro residue is located at a conserved position in TMD9 of SPP (P324; supplemental Fig. 5, available at www.jneurosci.org as supplemental material), suggesting that the $\alpha$-helix-breaking Pro residue may increase stability of GxGD proteases. Interestingly, this analysis revealed that one of the two Caenorhabditis elegans PS proteins, Hop-1, also contains a Pro at the homologous position (P329) whereas the other (Sel-12) does not. Consistent with the hypothesis that $\gamma$-secretase complexes centered around Hop-1 may have reduced dependency on the Aph2/NCT gene (Goutte et al., 2000), Aph2/Hop-1 double mutants are strongly affected but Aph-2/Sel-12 double mutants are not (Francis et al., 2002). This result indicates that Hop-1 is active without Aph-2, whereas Sel-12 is dependent on Aph-2 for full activity. NCT has been proposed to play a role in PS1 trafficking. In the absence of NCT, most PS1 proteins remain in the endoplasmic reticulum; PS1-NTFs were undetectable at the plasma membrane (Zhang et al., 2005). We have provided indirect evidence that at least some PS1 NTF-containing $\gamma$-secretase can reach the plasma membrane where it can activate a ligand-dependent Notch signal in the absence of NCT. Coupled with the genetic data (Francis et al., 2002) and with the analysis of NCT mutants (Chavez-Gutierrez et al., 2008), these observations favor a model in which NCT acts to stabilize $\gamma$-secretase but is not required for catalytic activity.

Although we cannot completely rule out the possibility that NCT contributes to $\gamma$-secretase activity and that this contribu- 

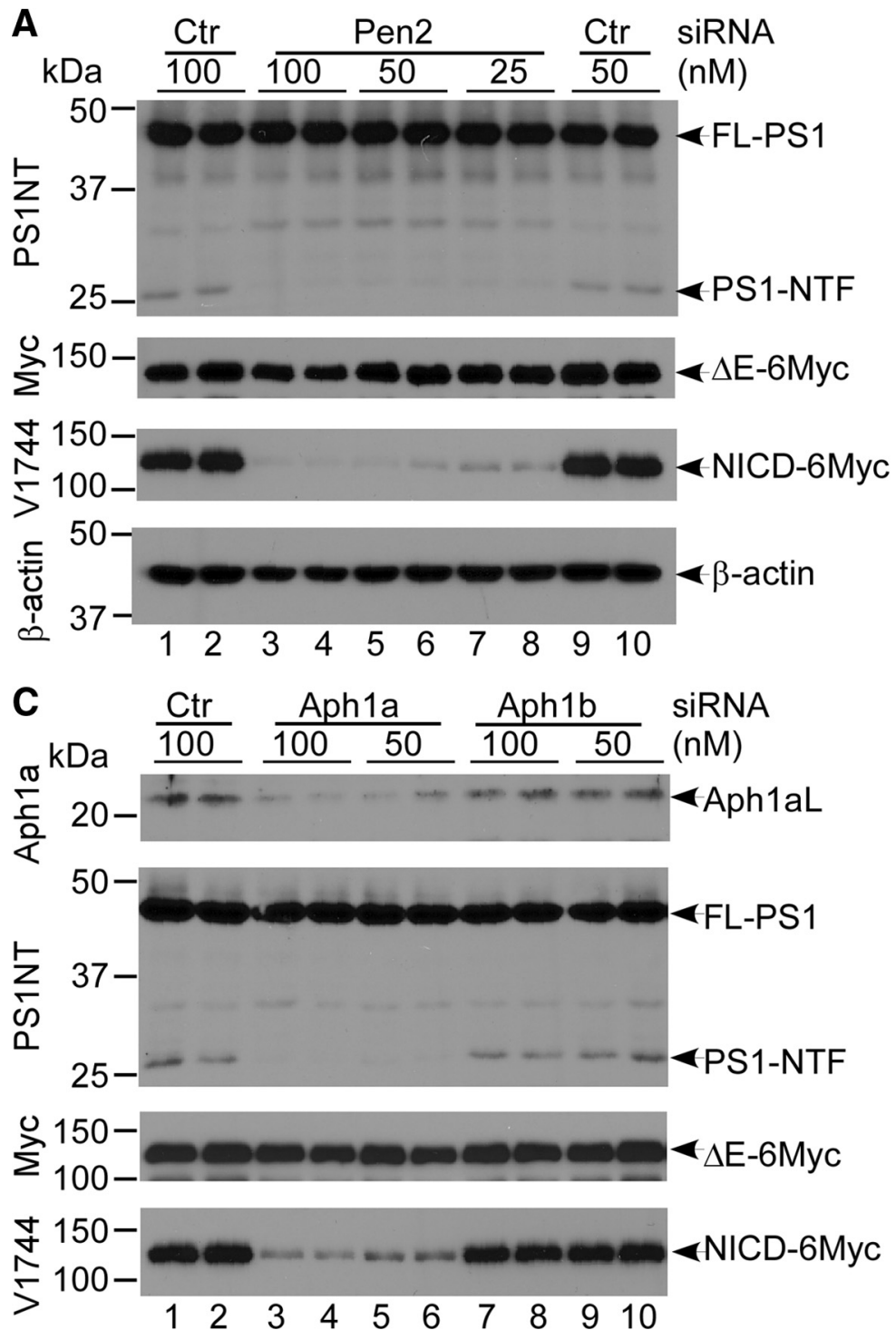

B

\section{Relative Pen2 mRNA levels}

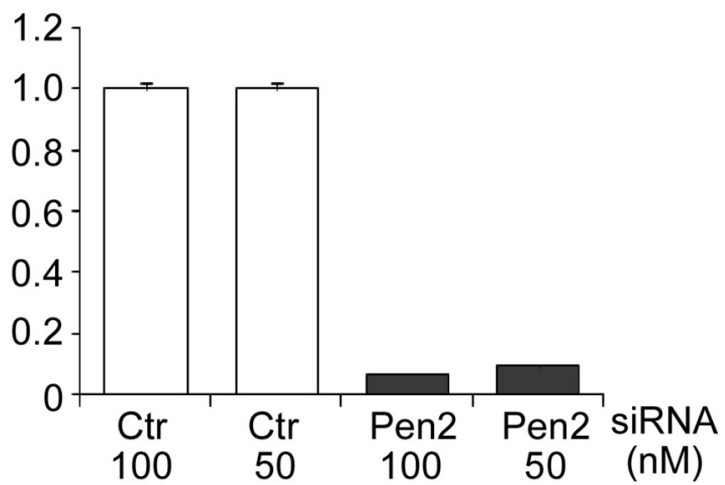

D

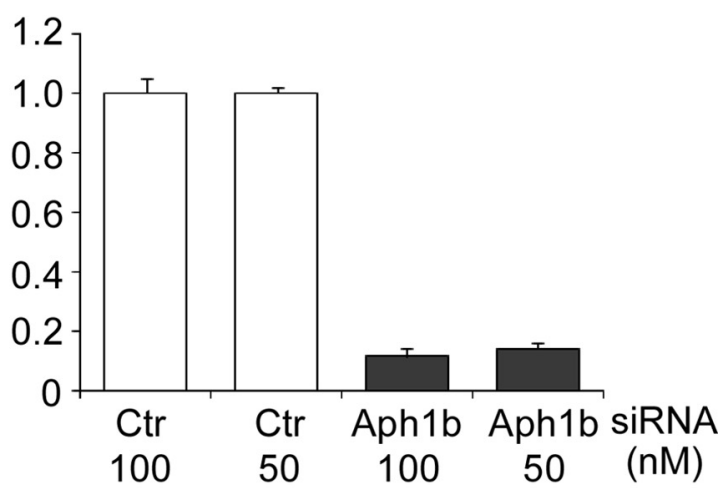

Figure 6. Pen2 and Aph1a are involved in the $\gamma$-secretase activity in the absence of NCT. Representative Western blots of NICD levels in Pen2 and Aph1 siRNA-transfected NCT ${ }_{\mathrm{RR}}{ }^{-/-}$cells are shown. A, Lysates from control (Ctr) siRNA- or Pen2 siRNA-transfected NCT ${ }^{-1-}$ cells were analyzed by Western blotting. Pen2 siRNA markedly decreased PS1-NTF level but not that of full-length PS1 (FL-PS1). Whereas Pen2 depletion slightly affected N1 $\triangle \mathrm{E}-6 \mathrm{MT}$ expression, it significantly diminished NICD generation in a dose-dependent manner. Note that the amounts of a PS1 fragment $(\sim 30 \mathrm{kDa})$ increased in Pen2 siRNA-treated samples. This PS1 fragment does not have $\gamma$-secretase activity. B, The efficiency of Pen2 knockdown ( $\sim 90 \%)$ was confirmed by qRT-PCR. C, Depletion of Aph1a in NCT ${ }_{R R}{ }^{-1-}$ cells markedly decreased PS1-NTF and NICD generation, whereas Aph1b siRNA treatment did not significantly affect NICD levels. D, Knockdown of Aph1b was confirmed by qRT-PCR.

tion requires E333 (Dries et al., 2009), our findings indicate that neither substrate recognition nor contribution to catalytic activity by NCT is necessary for $\gamma$-secretase activity. A distinct property of $\gamma$-secretase-mediated intramembrane cleavage is that it requires prior ectodomain shedding of the substrate; the large extracellular domain of NCT has been proposed to act as the gatekeeper that measures the size of the substrate ectodomain and the availability of a free $\mathrm{N}$ terminus ( $\mathrm{Hu}$ et al., 2002; De Strooper, 2005; Shah et al., 2005). However, we found that NCTdeficient $\gamma$-secretase activity still requires prior ectodomain shedding of its substrates (Fig. 3) (Mumm et al., 2000). It is unlikely that an unknown protein may function as NCT in $\mathrm{NCT}^{-1-}$ cells, and no additional NCT homologues have been found in the mouse or C. elegans genome. Indeed, a substrate-binding site has also been identified at the interface of PS1 NTF/CTF (Kornilova et al., 2005); this site may also be sensitive to the presence of a large extracellular domain. Additionally, the GxGD motif in
PS has been reported to contribute to substrate identification (Yamasaki et al., 2006). Furthermore, a PS relative, SPPLP2, requires substrate shedding yet does not require putative substrate binding partners (Martin et al., 2009).

How $\gamma$-secretase assembly occurs is a critical question in $\gamma$-secretase biology. One model posits that PS binds initially to Aph1 and NCT to form a subcomplex, and then this subcomplex binds to Pen2 to initiate PS endoproteolysis and NCT glycosylation (Takasugi et al., 2003). Alternatively, PS and Pen2 form a subcomplex in which PS endoproteolysis occurs while NCT and Aph1 form another subcomplex. The two subcomplexes then bind together (Spasic and Annaert, 2008). In both models, $\gamma$-secretase activity is conferred only after the complete assembly of the four-protein complex. The observations reported here suggest that a trimeric complex containing PS1, Pen2, and Aph1a is active but unstable and perhaps rapidly converted to the fourprotein complex in wild-type cells. Whether such a subcomplex 
occurs in the presence of NCT or only forms in its absence remains to be determined.

Why PS proteins require additional stabilizing components whereas SPP and SPPL do not and why PS2 is unable to act without NCT are interesting puzzles still to be resolved. The fact that $\gamma$-secretase activity could not be detected in PS ${ }^{\text {DKO }}$ cells (Figs. 1, 3, and 4) and that PS1 siRNA greatly diminished the residual $\gamma$-secretase activity in $\mathrm{NCT}^{-/-}$cells (Fig. $5 A$; supplemental Figs. 2 and 3, available at www.jneurosci.org as supplemental material for sequences) confirms the centrality of PS for $\gamma$-secretase activity. Interestingly, although PS possesses both substrate-binding and catalytic sites and thus has the potential to act as an enzyme on its own, knockdown of Pen2 and Aph1a eliminated $\gamma$-secretase activity in $\mathrm{NCT}^{-1-}$ cells (Fig. 6). Despite establishing that PS requires these two proteins, the current data cannot distinguish whether Pen2 and Aph1 are required for stabilizing PS1 or for enhancing its catalytic activity. If Aph1 or Pen2 are required only to stabilize PS1, it is conceivable that other unstable trimeric $\gamma$-secretase complexes can be formed in vitro. It is intriguing to suggest that isolation of such an active trimeric $\gamma$-secretase might facilitate the elucidation of its structure. It also appears that active Hop- 1 trimeric $\gamma$-secretase complexes may exist in vivo and can be isolated from Aph-2 mutants.

In conclusion, the present data demonstrate that NCT is dispensable for PS1-containing $\gamma$-secretase activity and cell surface transport but critical for stabilizing $\gamma$-secretase. This study also provides a biochemical explanation for the differential requirement for Aph2 shown by the two C. elegans PS proteins, Hop-1 and Sel-12.

\section{References}

Aster JC, Pear WS, Blacklow SC (2008) Notch signaling in leukemia. Annu Rev Pathol 3:587-613.

Bao J, Wolpowitz D, Role LW, Talmage DA (2003) Back signaling by the Nrg-1 intracellular domain. J Cell Biol 161:1133-1141.

Chavez-Gutierrez L, Tolia A, Maes E, Li T, Wong PC, de Strooper B (2008) $\mathrm{Glu}(332)$ in the Nicastrin ectodomain is essential for $\gamma$-secretase complex maturation but not for its activity. J Biol Chem 283:20096-20105.

Chen F, Yu G, Arawaka S, Nishimura M, Kawarai T, Yu H, Tandon A, Supala A, Song YQ, Rogaeva E, Milman P, Sato C, Yu C, Janus C, Lee J, Song L, Zhang L, Fraser PE, St George-Hyslop PH (2001) Nicastrin binds to membrane-tethered Notch. Nat Cell Biol 3:751-754.

Dejaegere T, Serneels L, Schafer MK, Van Biervliet J, Horre K, Depboylu C, Alvarez-Fischer D, Herreman A, Willem M, Haass C, Hoglinger GU, D'Hooge R, De Strooper B (2008) Deficiency of Aph1B/C- $\gamma$-secretase disturbs Nrg1 cleavage and sensorimotor gating that can be reversed with antipsychotic treatment. Proc Natl Acad Sci U S A 105:9775-9780.

De Strooper B (2003) Aph-1, Pen-2, and nicastrin with presenilin generate an active $\gamma$-secretase complex. Neuron 38:9-12.

De Strooper B (2005) Nicastrin: gatekeeper of the $\gamma$-secretase complex. Cell 122:318-320.

De Strooper B, Saftig P, Craessaerts K, Vanderstichele H, Guhde G, Annaert W, Von Figura K, Van Leuven F (1998) Deficiency of presenilin-1 inhibits the normal cleavage of amyloid precursor protein. Nature 391:387-390.

De Strooper B, Annaert W, Cupers P, Saftig P, Craessaerts K, Mumm JS, Schroeter EH, Schrijvers V, Wolfe MS, Ray WJ, Goate A, Kopan R (1999) A presenilin-1-dependent $\gamma$-secretase-like protease mediates release of Notch intracellular domain. Nature 398:518-522.

Dries DR, Shah S, Han YH, Yu C, Yu S, Shearman MS, Yu G (2009) Glu-333 of nicastrin directly participates in $\gamma$-secretase activity. J Biol Chem 284:29714-29724.

Edbauer D, Winkler E, Regula JT, Pesold B, Steiner H, Haass C (2003) Reconstitution of $\gamma$-secretase activity. Nat Cell Biol 5:486-488.

Fagan AM, Roe CM, Xiong C, Mintun MA, Morris JC, Holtzman DM (2007) Cerebrospinal fluid tau $\beta$ - amyloid $_{42}$ ratio as a prediction of cognitive decline in nondemented older adults. Arch Neurol 64:343-349.

Francis R, McGrath G, Zhang J, Ruddy DA, Sym M, Apfeld J, Nicoll M,
Maxwell M, Hai B, Ellis MC, Parks AL, Xu W, Li J, Gurney M, Myers RL, Himes CS, Hiebsch R, Ruble C, Nye JS, Curtis D (2002) aph-1 and pen-2 are required for Notch pathway signaling, gamma-secretase cleavage of betaAPP, and presenilin protein accumulation. Dev Cell 3:85-97.

Futai E, Yagishita S, Ishiura S (2009) Nicastrin is dispensable for $\gamma$-secretase protease activity in the presence of specific presenilin mutations. J Biol Chem 284:13013-13022.

Golde TE, Wolfe MS, Greenbaum DC (2009) Signal peptide peptidases: a family of intramembrane-cleaving proteases that cleave type 2 transmembrane proteins. Semin Cell Dev Biol 20:225-230.

Gordon WR, Vardar-Ulu D, Histen G, Sanchez-Irizarry C, Aster JC, Blacklow SC (2007) Structural basis for autoinhibition of Notch. Nat Struct Mol Biol 14:295-300.

Goutte C, Hepler W, Mickey KM, Priess JR (2000) aph-2 encodes a novel extracellular protein required for GLP-1-mediated signaling. Development 127:2481-2492.

Haass C (2004) Take five-BACE and the $\gamma$-secretase quartet conduct Alzheimer's amyloid $\beta$-peptide generation. EMBO J 23:483-488.

Haass C, Selkoe DJ (2007) Soluble protein oligomers in neurodegeneration: lessons from the Alzheimer's amyloid $\beta$-peptide. Nat Rev Mol Cell Biol 8:101-112.

Haass C, Steiner H (2002) Alzheimer disease gamma-secretase: a complex story of GxGD-type presenilin proteases. Trends Cell Biol 12:556-562.

Hayashi I, Urano Y, Fukuda R, Isoo N, Kodama T, Hamakubo T, Tomita T, Iwatsubo T (2004) Selective reconstitution and recovery of functional $\gamma$-secretase complex on budded baculovirus particles. J Biol Chem 279:38040-38046.

Herreman A, Hartmann D, Annaert W, Saftig P, Craessaerts K, Serneels L, Umans L, Schrijvers V, Checler F, Vanderstichele H, Baekelandt V, Dressel R, Cupers P, Huylebroeck D, Zwijsen A, Van Leuven F, De Strooper B (1999) Presenilin 2 deficiency causes a mild pulmonary phenotype and no changes in amyloid precursor protein processing but enhances the embryonic lethal phenotype of presenilin 1 deficiency. Proc Natl Acad Sci U S A 96:11872-11877.

$\mathrm{Hu}$ Y, Ye Y, Fortini ME (2002) Nicastrin is required for $\gamma$-secretase cleavage of the Drosophila Notch receptor. Dev Cell 2:69-78.

Huppert S, Le A, Schroeter EH, Mumm JS, Saxena MT, Milner LA, Kopan R (2000) Embryonic lethality in mice homozygous for a processing deficient allele of Notch1. Nature 405:966-970.

Huppert S, Ilagan MXG, De Strooper B, Kopan R (2005) Analysis of Notch function in presomitic mesoderm suggests a $\gamma$-secretase-independent role for presenilins in somite differentiation. Dev Cell 8:677-688.

Iwatsubo T (2004) Assembly and activation of the $\gamma$-secretase complex: roles of presenilin cofactors. Mol Psychiatry 9:8-10.

Kopan R, Ilagan MX (2009) The canonical Notch signaling pathway: unfolding the activation mechanism. Cell 137:216-233.

Kopan R, Schroeter EH, Weintraub H, Nye JS (1996) Signal transduction by activated mNotch: importance of proteolytic processing and its regulation by the extracellular domain. Proc Natl Acad Sci U S A 93:1683-1688.

Kornilova AY, Bihel F, Das C, Wolfe MS (2005) The initial substratebinding site of $\gamma$-secretase is located on presenilin near the active site. Proc Natl Acad Sci U S A 102:3230-3235.

Kukar TL, Ladd TB, Bann MA, Fraering PC, Narlawar R, Maharvi GM, Healy B, Chapman R, Welzel AT, Price RW, Moore B, Rangachari V, Cusack B, Eriksen J, Jansen-West K, Verbeeck C, Yager D, Eckman C, Ye W, Sagi S, et al. (2008) Substrate-targeting $\gamma$-secretase modulators. Nature 453:925-929.

Lee J, Basak JM, Demehri S, Kopan R (2007) Bi-compartmental communication contributes to the opposite proliferative behavior of Notch1deficient hair follicle and epidermal keratinocytes. Development 134: 2795-2806.

Li T, Ma G, Cai H, Price DL, Wong PC (2003) Nicastrin is required for assembly of presenilin $/ \gamma$-secretase complexes to mediate Notch signaling and for processing and trafficking of $\beta$-amyloid precursor protein in mammals. J Neurosci 23:3272-3277.

Li YM, Xu M, Lai MT, Huang Q, Castro JL, DiMuzio-Mower J, Harrison T, Lellis C, Nadin A, Neduvelil JG, Register RB, Sardana MK, Shearman MS, Smith AL, Shi XP, Yin KC, Shafer JA, Gardell SJ (2000) Photoactivated $\gamma$-secretase inhibitors directed to the active site covalently label presenilin 1. Nature 405:689-694.

Ma G, Li T, Price DL, Wong PC (2005) APH-1a is the principal mammalian 
APH-1 isoform present in $\gamma$-secretase complexes during embryonic development. J Neurosci 25:192-198.

Martin L, Fluhrer R, Haass C (2009) Substrate requirements for SPPL2bdependent regulated intramembrane proteolysis. J Biol Chem 284:56625670 .

Miele L, Miao H, Nickoloff BJ (2006) NOTCH signaling as a novel cancer therapeutic target. Curr Cancer Drug Targets 6:313-323.

Mumm JS, Schroeter EH, Saxena MT, Griesemer A, Tian X, Pan DJ, Ray WJ, Kopan R (2000) A ligand-induced extracellular cleavage regulates $\gamma$-secretase-like proteolytic activation of Notch1. Mol Cell 5:197-206.

Nguyen V, Hawkins C, Bergeron C, Supala A, Huang J, Westaway D, St George-Hyslop P, Rozmahel R (2006) Loss of nicastrin elicits an apoptotic phenotype in mouse embryos. Brain Res 1086:76-84

Ni CY, Murphy MP, Golde TE, Carpenter G (2001) gamma-Secretase cleavage and nuclear localization of ErbB-4 receptor tyrosine kinase. Science 294:2179-2181.

Ong CT, Sedy JR, Murphy KM, Kopan R (2008) Notch and presenilin regulate cellular expansion and cytokine secretion but cannot instruct Th1/ Th2 fate acquisition. PLoS One 3:e2823.

Rand DM, Grimm MLM, Artavanis-Tsakonas S, Patriub V, Blacklow CS, Sklar CJ, Aster CJ (2000) Calcium depletion dissociates and activates heterodimeric Notch receptors. Mol Cell Biol 20:1825-1835.

Roy M, Pear WS, Aster JC (2007) The multifaceted role of Notch in cancer. Curr Opin Genet Dev 17:52-59.

Schroeter EH, Ilagan MX, Brunkan AL, Hecimovic S, Li YM, Xu M, Lewis HD, Saxena MT, De Strooper B, Coonrod A, Tomita T, Iwatsubo T, Moore CL, Goate A, Wolfe MS, Shearman M, Kopan R (2003) A presenilin dimer at the core of the $\gamma$-secretase enzyme: insights from parallel analysis of Notch 1 and APP proteolysis. Proc Natl Acad Sci U S A 100:13075-13080.

Selkoe D, Kopan R (2003) Notch and Presenilin: regulated intramembrane proteolysis links development and degeneration. Annu Rev Neurosci 26:565-597.

Selkoe DJ, Wolfe MS (2007) Presenilin: running with scissors in the membrane. Cell 131:215-221.

Serneels L, Dejaegere T, Craessaerts K, Horre K, Jorissen E, Tousseyn T, Hebert S, Coolen M, Martens G, Zwijsen A, Annaert W, Hartmann D, De Strooper B (2005) Differential contribution of the three Aph1 genes to $\gamma$-secretase activity in vivo. Proc Natl Acad Sci U S A 102:1719-1724.

Serneels L, Van Biervliet J, Craessaerts K, Dejaegere T, Horre K, Van Houtvin T, Esselmann H, Paul S, Schafer MK, Berezovska O, Hyman BT, Sprangers B, Sciot R, Moons L, Jucker M, Yang Z, May PC, Karran E, Wiltfang J, D'Hooge R, et al. (2009) $\gamma$-Secretase heterogeneity in the Aph1 subunit: relevance for Alzheimer's disease. Science 324:639-642.

Shah S, Lee SF, Tabuchi K, Hao YH, Yu C, LaPlant Q, Ball H, Dann CE 3rd, Sudhof T, Yu G (2005) Nicastrin functions as a $\gamma$-secretase-substrate receptor. Cell 122:435-447.

Shirotani K, Edbauer D, Kostka M, Steiner H, Haass C (2004) Immature nicastrin stabilizes APH- 1 independent of PEN-2 and presenilin: identi- fication of nicastrin mutants that selectively interact with APH-1. J Neurochem 89:1520-1527.

Spasic D, Annaert W (2008) Building $\gamma$-secretase: the bits and pieces. J Cell Sci 121:413-420.

Tagami S, Okochi M, Yanagida K, Ikuta A, Fukumori A, Matsumoto N, Ishizuka-Katsura Y, Nakayama T, Itoh N, Jiang J, Nishitomi K, Kamino K, Morihara T, Hashimoto R, Tanaka T, Kudo T, Chiba S, Takeda M (2008) Regulation of Notch signaling by dynamic changes in the precision of S3 cleavage of Notch-1. Mol Cell Biol 28:165-176.

Takasugi N, Tomita T, Hayashi I, Tsuruoka M, Niimura M, Takahashi Y, Thinakaran G, Iwatsubo T (2003) The role of presenilin cofactors in the $\gamma$-secretase complex. Nature 422:438-441.

Tanzi RE, Bertram L (2005) Twenty years of the Alzheimer's disease amyloid hypothesis: a genetic perspective. Cell 120:545-555.

Thinakaran G, Koo EH (2008) Amyloid precursor protein trafficking, processing, and function. J Biol Chem 283:29615-29619.

Tomita T (2009) Secretase inhibitors and modulators for Alzheimer's disease treatment. Expert Rev Neurother 9:661-679.

Tomita T, Tokuhiro S, Hashimoto T, Aiba K, Saido TC, Maruyama K, Iwatsubo T (1998) Molecular dissection of domains in mutant presenilin 2 that mediate overproduction of amyloidogenic forms of amyloid $\beta$ peptides. Inability of truncated forms of PS2 with familial Alzheimer's disease mutation to increase secretion of A $\beta 42$. J Biol Chem 273:21153-21160.

van Tetering G, van Diest P, Verlaan I, van der Wall E, Kopan R, Vooijs M (2009) The metalloprotease ADAM10 is required for notch1 S2 cleavage. J Biol Chem 284:31018-31027.

Weihofen A, Lemberg MK, Friedmann E, Rueeger H, Schmitz A, Paganetti P, Rovelli G, Martoglio B (2003) Targeting presenilin-type aspartic protease signal peptide peptidase with $\gamma$-secretase inhibitors. J Biol Chem 278:16528-16533.

Wolfe MS (2008) $\gamma$-Secretase inhibition and modulation for Alzheimer's disease. Curr Alzheimer Res 5:158-164.

Wolfe MS (2009) Intramembrane-cleaving proteases. J Biol Chem 284: 13969-13973.

Wolfe MS, Xia W, Ostaszewski BL, Diehl TS, Kimberly WT, Selkoe DJ (1999) Two transmembrane aspartates in presenilin-1 required for presenilin endoproteolysis and $\gamma$-secretase activity. Nature 398:513-517.

Yamasaki A, Eimer S, Okochi M, Smialowska A, Kaether C, Baumeister R, Haass C, Steiner H (2006) The GxGD motif of presenilin contributes to catalytic function and substrate identification of $\gamma$-secretase. J Neurosci 26:3821-3828.

Zhang YW, Luo WJ, Wang H, Lin P, Vetrivel KS, Liao F, Li F, Wong PC, Farquhar MG, Thinakaran G, Xu H (2005) Nicastrin is critical for stability and trafficking but not association of other presenilin $/ \gamma$-secretase components. J Biol Chem 280:17020-17026.

Zhao G, Mao G, Tan J, Dong Y, Cui MZ, Kim SH, Xu X (2004) Identification of a new presenilin-dependent $\zeta$-cleavage site within the transmembrane domain of amyloid precursor protein. J Biol Chem 279: 50647-50650. 